\title{
Transforming growth factor- $\beta 1$ up-regulates p15, p21 and p27 and blocks cell cycling in G1 in human prostate epithelium
}

\author{
C N Robson, V Gnanapragasam, R L Byrne, A T Collins \\ and D E Neal
}

School of Surgical Sciences, Medical School, Framlington Place, University of Newcastle upon Tyne NE2 4HH, UK

(Requests for offprints should be addressed to D E Neal)

\begin{abstract}
Transforming growth factor- $\beta 1$ (TGF $\beta 1$ ) is inhibitory to most epithelia, but its role in the control of proliferation of prostatic epithelium is unclear. In some cells, TGF $\beta 1$ inhibition is achieved by up-regulation of cyclindependent kinase (cdk) inhibitors including p15, p21 and $\mathrm{p} 27$.

Our aims were to determine whether the effects of TGF $\beta 1$ on human prostatic epithelial cell cycle kinetics were mediated by alterations in the levels of the cdk inhibitors p15, p16, p21 and p27 and hypophosphorylated retinoblastoma protein $(\mathrm{Rb})$.

Human prostatic epithelial cells in primary culture were grown in the presence of TGF $\beta 1(0-10 \mathrm{ng} / \mathrm{ml})$ for up to 4 days and proliferation assessed using a $\left[{ }^{3} \mathrm{H}\right]$ thymidine uptake assay. Levels of p15, p16, p21 and p27 were measured at both mRNA and protein level by means of
\end{abstract}

a reverse transcriptase PCR-based assay and Western analysis. $\mathrm{Rb}$ and $\mathrm{cdk} 2$ levels were measured.

Exogenous TGF $\beta 1(0-5 \mathrm{ng} / \mathrm{ml})$ inhibited proliferation. This was associated with blocking of the cell cycle at G1, and up to 4-fold increases in p15, p21 and p27 mRNA levels, but no change was observed in p16 mRNA levels; these changes were not blocked by cycloheximide. Increased levels of p15, p21 and p27 protein were also accompanied by increased levels of hypo-phosphorylated $\mathrm{Rb}$ and decreased cdk2 kinase activity.

TGF $\beta 1$ has mainly inhibitory effects on benign human prostatic epithelium, which are caused by up-regulation of cdk inhibitors, hypo-phosphorylation of $\mathrm{Rb}$ and delaying of the cell cycle in G1.

Journal of Endocrinology (1999) 160, 257-266

\section{Introduction}

Benign enlargement of the prostate (benign prostatic hyperplasia $(\mathrm{BPH})$ ) is very common, being found in $40 \%$ of men aged greater than 60 years and necessitating an operation in about 15\%. Complex endocrine, autocrine and paracrine interactions between prostatic epithelium and stroma may be responsible for the formation of $\mathrm{BPH}$. Prostate cancer is the second most common malignancy in men, and in its advanced stages is unresponsive to androgen control, which may be mediated by alterations in peptide growth factor function.

Transforming growth factor- $\beta 1$ (TGF $\beta 1$ ) is widely distributed. In general, TGF $\beta 1$ stimulates mesenchyme and inhibits epithelial growth (Moses et al. 1990). TGF $\beta 1$ and TGF $\beta 2$ have been identified in human prostate and implicated in prostatic disease (Knabbe et al. 1993, Truong et al. 1993). Addition of TGF $\beta 1$ to cultured prostatic epithelial and stromal cells has been reported to inhibit proliferation in both cell types (Sutkowski et al. 1992). However, low levels of TGF $\beta 1$ have been shown to result in small increases $(1 \cdot 5$-fold $)$ in cell proliferation in both stroma and epithelium (Collins et al. 1996).

Cell cycle progression is governed by a series of cyclindependent kinases (cdks) whose function is dependent on their phosphorylation status and association with specific cyclins (Sherr 1994). Positive regulatory factors include growth factors, transcription factors, cyclins and cdks. Negative regulatory forces are provided by tumour suppressor proteins, notably those encoded by the tumour suppressor genes, $\mathrm{p} 53$ and $\mathrm{Rb}$ (retinoblastoma) and the $\mathrm{cdk}$ inhibitors (CDKIs). The D family of cyclins complex with cdk4 and cdk6, while the principal partner of cyclin $\mathrm{E}$ is $c d k 2$. The $\mathrm{Rb}$ protein binds to and sequesters specific proteins necessary for cell cycle progression, thereby preventing cell cycle progression. During G1 phase, Rb protein is phosphorylated by cyclin $\mathrm{D} / \mathrm{cdk} 4$ and cyclin $\mathrm{D} / \mathrm{cdk} 6$ complexes. Phosphorylation of $\mathrm{Rb}$ inactivates it and allows the release of E2F, thereby allowing entry of cells into S phase (Weinberg 1995).

CDKIs control the phosphorylation status of $\mathrm{Rb}$ protein (Clurman \& Roberts 1995). The Kip/cip members, which include $\mathrm{p} 21, \mathrm{p} 27$ and $\mathrm{p} 57$, are capable of binding to 
and inhibiting most cyclin/cdk complexes. Their expression is dependent on up-stream events which are activated by physiological signals such as DNA damage, serum deprivation or contact inhibition. Up-regulation of p21 is thought to be the means by which p53 places dividing cells in G1 phase arrest in response to DNA damage (Macleod et al. 1995). In contrast the INK4 family, which includes p15, p16, p18 and p19, bind to and inactivate D-type cyclins. Studies of p16 and p15 (INK4a and INK4b) have shown that they can function as tumour suppressors (Cairns et al. 1994, Quelle et al. 1995).

In keratinocytes, p15 is up-regulated 30-fold by $2 \mathrm{ng} /$ ml TGF $\beta 1$ (Hannon \& Beach 1994), though this study failed to demonstrate changes in $\mathrm{p} 16$ or $\mathrm{p} 27$. In gastric cancer cell lines, TGF $\beta 1$ up-regulates p21 about 3-fold (Akagi et al. 1996), but produces only slight changes in expression of p27. Although p27 was originally identified in cells treated with TGF $\beta 1$ (Polyak et al. 1994), recent studies have failed to demonstrate significant changes in mRNA levels, but protein levels may be altered by sequestration to cyclin D. Decrease in cdk4 following application of TGF $\beta 1$ may release previously bound p27 protein.

The purpose of this study was to investigate how high levels of TGF $\beta 1$ result in inhibition of human prostate cells in primary culture. We believe that investigation of CDKI regulation by TGF $\beta 1$ in the prostate has not been performed previously. The results show the complexity of growth control in the human prostate epithelium and that p15, p21 and p27 are the main mediators of inhibition resulting in an accumulation of cells in G1.

\section{Materials and Methods}

Preparation of primary cultures of human prostatic epithelial and stromal cells

Prostatic tissue was obtained from men undergoing open prostatectomy and transurethral prostatic resection for bladder outflow obstruction. Specimens were dissected into $1-2 \mathrm{~mm}^{3}$ pieces, but representative chips were retained to confirm the histological diagnosis of $\mathrm{BPH}$. Tissue was then incubated at $37^{\circ} \mathrm{C}$ for $20 \mathrm{~h}$ with collagenase type I $(2000 \mathrm{IU} / \mathrm{ml})$ (Lorne Laboratories, Reading, UK) in RPMI-1640 (Life Technologies Ltd, Paisley, Scotland) containing 5\% foetal calf serum (Life Technologies Ltd). The digest was centrifuged at $800 \boldsymbol{g}$ for $10 \mathrm{~min}$ and supernatant discarded. The cell pellet was re-suspended in $10 \mathrm{ml}$ Dulbecco 'A' PBS (Oxoid Ltd, Basingstoke, Hampshire, UK) and centrifuged at $800 \boldsymbol{g}$ for $10 \mathrm{~min}$. This latter step was repeated. The cell pellet was then re-suspended in RPMI-1640 and centrifuged twice at $400 \mathrm{~g}$ for $1 \mathrm{~min}$. Epithelial cells were collected as a pellet following each centrifugation. Stromal cells remained in the supernatant. Epithelium was grown in primary growth medium in $75 \mathrm{~cm}^{2}$ tissue culture flasks
(Becton Dickinson, Oxford, UK) at $37^{\circ} \mathrm{C}$ in $5 \% \mathrm{CO}_{2}$. This method has been shown to produce primary cultures that are at least 95\% pure (Collins et al. 1994).

\section{Cell culture media}

Epithelial cells were cultured in complete WAJC404 serum-free medium (WAJC-404 basal medium; Life Technologies Ltd) supplemented with insulin $(2.5 \mathrm{mg} / \mathrm{ml}$; Sigma Chemical Co. Ltd, Poole, Dorset, UK), dexamethasone $(1 \mu \mathrm{M}$; Sigma), epidermal growth factor (EGF) (10 ng/ml; Sigma), bovine pituitary extract $(25 \mathrm{mg} / \mathrm{ml}$; Sigma), cholera toxin (10 ng/ml; Sigma), heparin (25 ng/ $\mathrm{ml}$; Sigma), penicillin (100 units/ml; Life Technologies Ltd) and streptomycin $(100 \mathrm{mg} / \mathrm{ml}$; Life Technologies Ltd). WAJC-404 medium has a low $\mathrm{Ca}^{2+}$ concentration that prohibits stromal cell growth. Basal epithelial growth medium contained all the above supplements apart from EGF and bovine pituitary extract and included low levels of fibroblast growth factor-2 (FGF2) $\left(10^{-9} \mathrm{M}\right)$.

\section{Mitogenesis assays and addition of TGF $\beta 1$}

Sub-confluent primary monolayer cultures of epithelial cells were washed with PBS and then detached using 0.25\% trypsin, $0 \cdot 02 \%$ EDTA (Life Technologies Ltd). Cells were plated at a density of $1 \times 10^{4}$ cells/well in 96-well plates in primary epithelial growth medium. After $24 \mathrm{~h}$, primary growth medium was removed and replaced by basal medium. Cells were then cultured for 4 days, after which $1 \mu \mathrm{Ci}\left[6-{ }^{3} \mathrm{H}\right]$ thymidine $(5 \cdot 0 \mathrm{Ci} / \mathrm{mmol}$, Amersham International, Amersham, Bucks, UK) in basal epithelial growth medium was added to each well. Cells were harvested $12 \mathrm{~h}$ later. Medium was aspirated from each well and $50 \mu \mathrm{l}$ trypsin $(2.5 \%)$ was added. After $20 \mathrm{~min}$, $10 \%$ trichloroacetic acid $\left(4^{\circ} \mathrm{C}\right)$ was added and cells incubated at $4{ }^{\circ} \mathrm{C}$ for $2 \mathrm{~h}$. Plates were harvested on filter mats (Tomtec cell harvester, Wallac, Milton Keynes, Oxfordshire, UK), dried at $60{ }^{\circ} \mathrm{C}$ for $30 \mathrm{~min}$ and counted following the addition of scintillation fluid (BetaPlate Scint; Wallac, Milton-Keynes, UK) using a 1450 Microbeta Plus scintillation counter (Wallac). Recombinant TGF $\beta 1$ protein (R\&D Systems, Abingdon, UK) was added to the culture medium at concentrations from $0 \cdot 001$ to $100 \mathrm{ng} / \mathrm{ml}$. For some experiments investigating the duration of exposure to TGF $\beta 1$ on cell proliferation, three low concentrations were used $(0.03,0.01$ and $0.003 \mathrm{ng} / \mathrm{ml}$ ). In order to determine the effects of TGF $\beta 1$ on expression of cdks, cells were exposed to $0,0 \cdot 03,0 \cdot 1$, $0 \cdot 3,1$ and $5 \mathrm{ng} / \mathrm{ml}$ for $96 \mathrm{~h}$.

To test the effect of TGF $\beta 1$ on proliferation, TGF $\beta 1$ neutralising antibody $(10-30 \mu \mathrm{g} / \mathrm{ml}$; R\&D Systems) or TGF $\beta 2$ neutralising antibody $(10-30 \mu \mathrm{g} / \mathrm{ml} ; \quad \mathrm{R} \& \mathrm{D}$ Systems) was added to the epithelial compartment and $\left[{ }^{3} \mathrm{H}\right]$ thymidine incorporation was measured after 4 days as described. Both anti-TGF $\beta 1$ and anti-TGF $\beta 2$ antibodies 
are highly specific and do not cross-react with each other. The effect of neutralising antibody was carried out in the absence of low levels of FGF2 as we wished to simply determine whether TGF $\beta 1$ was present.

\section{Reverse transcriptase-polymerase chain reaction (RT-PCR)}

Cell cultures were lysed directly into guanidinium thiocyanate and total RNA was extracted according to Chomczynski \& Sacchi (1987). First strand cDNA was made from $5 \mu \mathrm{g}$ RNA using AMV Reverse Transcriptase (Krammel Biotech, Cramlington, UK). PCR was performed with $1 / 25$ th of the cDNA using Taq polymerase (Perkin Elmer Cetus, Cheshire, UK) and standard PCR conditions. For glyceraldehyde-3-phosphate dehydrogenase (GAPDH), 25 cycles of PCR were performed using the following oligonucleotides: 5' AGT CAA CGG ATT TGG TCG TA $3^{\prime}$ and $5^{\prime}$ AAA TGA GCC CCA GCC TTC T 3 ' to produce a 315 bp product. For p15, p16, p21 and p 27 the cDNA fragments were amplified using 35 cycles of PCR with the following oligonucleotide pairs: p15 5' GGC GCG CGA TCC AGG TCA 3', 5' GAA CCT GGC GTC AGT CCC 3' (285 bp product); p16 5' CGG AAG GTC CCT CAG ACA TC 3', 5' TCA TGA AGT CGA CAG CTT CCG 3' (385 bp product); p21 5' CTC AGA GGA GGC GCC ATG 3', 5' GGG CGG ATT AGG GCT TCC 3' (517 bp product); p27 5' AGG ATG TCA GCG GGA GCC G G 3', 5' CTT CTT GGG CGT CTG CTC CA 3' (250 bp product). Oligonucleotides were designed to be highly specific and to cross intron-exon boundaries. A range of PCR cycles were evaluated (GAPDH, 20-25 cycles; p15, p16, p21, p27, 30-35 cycles) to determine the linear range necessary for cDNA amplification. To enable quantification of cDNA products the PCR reactions were modified to include $20 \mu \mathrm{M}$ dNTPs and $0 \cdot 25 \mu \mathrm{Ci}\left[\alpha-{ }^{32} \mathrm{P}\right] \mathrm{dATP}$ (ICN, Thame, Oxon, UK). PCR products were resolved on $4 \% 90 \mathrm{mM}$ Tris, $90 \mathrm{mM}$ boric acid, $2 \mathrm{mM}$ EDTA-polyacrylamide gels. The gels were dried and exposed to autoradiography film or a phosphor screen (Molecular Dynamics, Chesham, Bucks, UK) to allow accurate quantification of products. Results were expressed as the ratio of CDKI: GAPDH. A range of PCR cycles were employed for each cDNA to verify amplification was in the linear range of the PCR process.

\section{Addition of cycloheximide}

Cells were exposed to $10 \mathrm{mg} / \mathrm{ml}$ cycloheximide (Sigma) for $1 \mathrm{~h}$ and $5 \mathrm{ng} / \mathrm{ml}$ TGF $\beta 1$ subsequently added for 0,12 , 24, 48 and $96 \mathrm{~h}$.

\section{Western blotting}

Following exposure to TGF $\beta 1$, cultured cells were detached with trypsin and immediately re-suspended in
SDS loading buffer and boiled for $10 \mathrm{~min}$. Electrophoresis was performed using 12\% SDS-polyacrylamide gels (Bio-Rad Minigel System, Bio-Rad Laboratories, Hemel Hempstead, Herts, UK) and proteins were transferred to nitrocellulose membranes (Amersham International). Membranes were blocked in $20 \mathrm{mM}$ Tris- $\mathrm{HCl} \mathrm{pH} 7 \cdot 5$, $500 \mathrm{mM} \mathrm{NaCl}$ containing 5\% dried milk and $0 \cdot 1 \%$ Tween-20 and probed with rabbit anti-p15 polyclonal antibodies (Santa Cruz), rabbit anti-p16 polyclonal antibody (Novocastra, Newcastle, Tyne and Wear, UK; Santa Cruz, CA, USA), mouse anti-p21 monoclonal antibody (Santa Cruz), rabbit anti-p27 polyclonal antibody (Santa Cruz), mouse anti-Rb monoclonal antibody (PharMingen, San Diego, CA, USA) and mouse anti- $\beta$ tubulin monoclonal antibody (Sigma) for $1 \mathrm{~h}$. Following a second incubation with peroxidase-conjugated anti-mouse or anti-rabbit antibodies (Dako, Ely, Cambridgeshire, UK) proteins were visualised using an enhanced chemiluminescent detection system (Amersham International).

\section{Flow cytometry}

Flow cytometry was used to analyse the effects of TGF $\beta 1$ on the cell cycle and to quantify immunofluorescence for the cellular proliferation marker Ki-67. All manipulations were performed on ice to minimise damage to cells. Cells were detached from Petri dishes using PBS, 0.02\% EDTA and washed using an automatic cell washer (Diacent 2000, Rosslab, Macclesfield, UK). For studies involving immunofluorescence staining, the cells were fixed by re-suspension in $200 \mu \mathrm{l}$ cold methanol and incubation at $-70{ }^{\circ} \mathrm{C}$, then washed by centrifugation. Pellets were re-suspended in isoton (Coulter, Luton, Bedfordshire, UK) and saponin was added to $1 \%$ to permeabilise the cells. Cells were incubated in the presence of fluorescein isothiocyanate (FITC)-conjugated mouse anti-Ki-67 monoclonal antibody (Immunotech, Marseille, France) on ice for $20 \mathrm{~min}$ at a 1:20 dilution. Unbound antibody was removed by centrifugal washing. Control cell pellets were re-suspended in FITC-conjugated goat anti-mouse antibody (Becton Dickinson) at an equivalent concentration and treated in an identical fashion. Cells were washed by centrifugation and re-suspended in isoton containing propidium iodide $(0.25 \mathrm{mg} / \mathrm{ml})$ and RNaseA $(1 \mathrm{mg} / \mathrm{ml})$ to stain DNA. Samples were analysed on a bench-top FACScan flow cytometer (Becton Dickinson); cellular fluorescence was measured after argon laser excitation at $488 \mathrm{~nm}$. Data were analysed using the LYSIS II software package (Becton Dickinson) and statistics calculated using Microsoft Excel.

\section{Immunoprecipitation and histone H1 kinase assays}

Cells were washed with ice-cold PBS, pelleted and lysed in immunoprecipitation buffer $(50 \mathrm{mM}$ Tris $-\mathrm{HCl} \mathrm{pH} 7 \cdot 5$, $150 \mathrm{mM} \mathrm{NaCl}, 0 \cdot 5 \% \mathrm{NaPO}_{4}, 50 \mathrm{mM} \mathrm{NaF}, 0 \cdot 2 \mathrm{mM}$ 


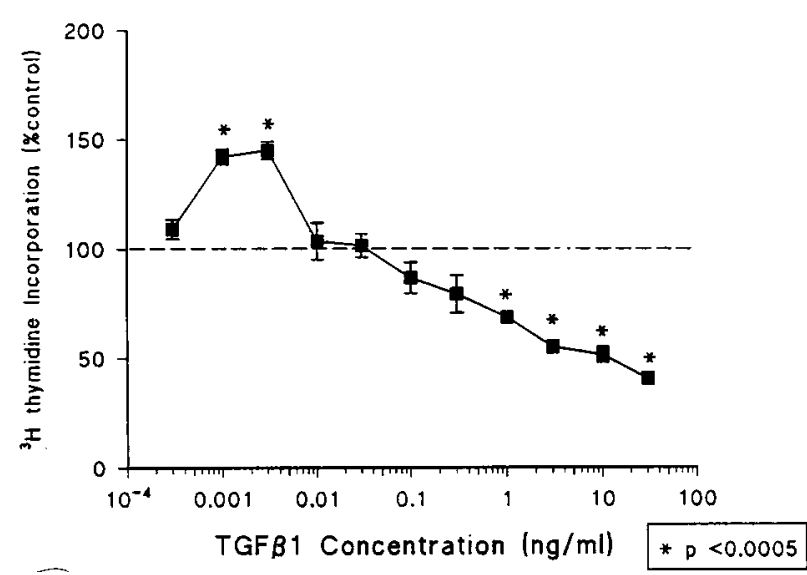

Figure 1 Effect of exogenous TGF $\beta 1$ on epithelial proliferation. Exogenous TGF $\beta 1(0 \cdot 0003-0 \cdot 3 \mathrm{ng} / \mathrm{ml})$ was added directly in basal epithelial medium with $10^{-9}$ M FGF2 to epithelial cells. All measurements were performed in quadruplicate. $\left[{ }^{3} \mathrm{H}\right]$ Thymidine incorporation was measured after 4 days. Results are expressed as a percentage of the untreated control (epithelium in basal medium with $10^{-9}$ M FGF2). Statistical analysis compares each point against untreated control.

$\mathrm{NaVaO}_{4}, 1 \mathrm{mM}$ polymethylsulphonyl fluoride (PMSF), $1 \mathrm{mM}$ dithiothreitol (DTT), $25 \mu \mathrm{g} / \mathrm{ml}$ aprotinin, $25 \mu \mathrm{g} /$ $\mathrm{ml}$ leupeptin, $25 \mu \mathrm{g} / \mathrm{ml}$ pepstatin). Lysates were cleared by centrifugation at $33000 \boldsymbol{g}$ for $20 \mathrm{~min}$. Two hundred micrograms total protein were incubated for $2 \mathrm{~h}$ with anti-cdk2 antibody (Santa Cruz) which had previously been incubated with protein A-agarose beads (Pharmacia, Milton Keynes, Bucks, UK). Cdk2-associated kinase activity was assayed in anti-cdk2 immune complexes. The beads were washed three times in immunoprecipitation buffer and three times in kinase reaction buffer $(50 \mathrm{mM}$ Hepes $\mathrm{pH} 7 \cdot 5,10 \mathrm{mM} \mathrm{MgCl} 2,5 \mathrm{mM} \mathrm{MnCl}_{2}, 1 \mathrm{mM}$ DTT, $50 \mathrm{mM} \mathrm{NaF}, 0.2 \mathrm{mM} \mathrm{NaVaO}, 1 \mathrm{mM}$ PMSF, $25 \mu \mathrm{g} / \mathrm{ml}$ aprotinin, $25 \mu \mathrm{g} / \mathrm{ml}$ leupeptin, $25 \mu \mathrm{g} / \mathrm{ml}$ pepstatin). Kinase reactions were performed at $37^{\circ} \mathrm{C}$ for $30 \mathrm{~min}$ in $20 \mu \mathrm{l}$ kinase buffer containing $0 \cdot 1 \mu \mathrm{Ci}$ $\left[\gamma-{ }^{32}\right.$ P]ATP (ICN, UK) and $2 \mu \mathrm{g}$ histone H1 substrate (Boehringer-Mannheim, Lewes, East Sussex, UK). The reactions were terminated with $5 \times$ SDS sample buffer. Following boiling for $5 \mathrm{~min}$ and centrifugation for $2 \mathrm{~min}$ at $5000 \mathrm{~g}$ the supernatants were resolved on $12 \%$ denaturing polyacrylamide gels. Radioactivity was detected by autoradiography or phosphor imager (Molecular Dynamics, UK).

\section{Statistical analysis}

Statistical significance was assessed using ANOVA (InStat GraphPad Software, San Diego, CA, USA). Twotailed probabilities of less than 0.05 were considered as significant.

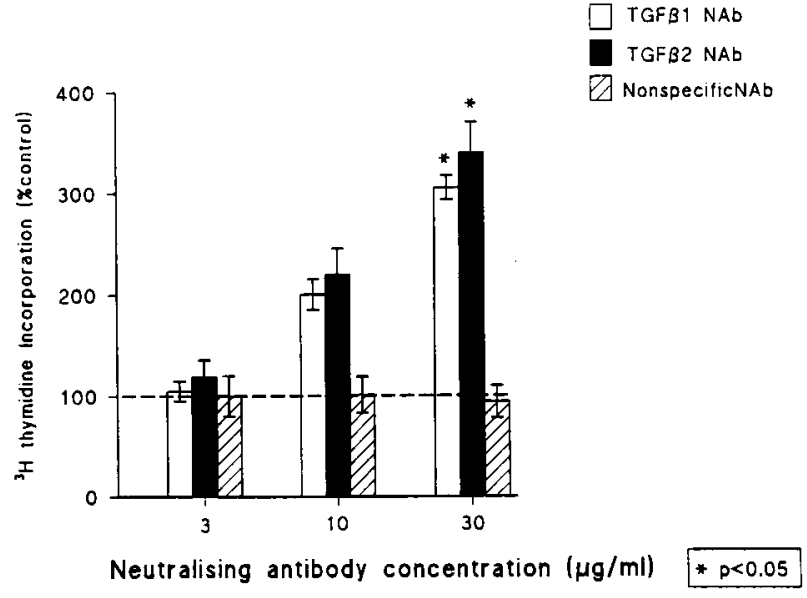

Figure 2 Effect of TGF $\beta 1$, TGF $\beta 2$ and non-specific neutralising antibodies on epithelial proliferation. Neutralising antibodies to TGF $\beta 1$, TGF $\beta 2$ and a non-specific chicken antibody were added to epithelial cells in basal epithelial medium. All measurements were performed in quadruplicate. $\left[{ }^{3} \mathrm{H}\right]$ Thymidine incorporation was measured after 4 days. Results are expressed as a percentage of untreated control (epithelium in basal medium). Statistical analysis compares each point against untreated control. $\mathrm{NAb}=$ neutralising antibody.

\section{Results}

\section{Effect of TGF $\beta 1$ on epithelial proliferation}

The effect of varying concentrations of TGF $\beta 1$ on epithelial proliferation from a representative primary culture is shown in Fig. 1. In the presence of low levels of FGF2 $\left(10^{-9} \mathrm{M}\right)$, low TGF $\beta 1$ concentrations $(0 \cdot 001-0 \cdot 003 \mathrm{ng} /$ $\mathrm{ml}$ ) caused stimulation of proliferation by $50 \%$ compared with control levels (control $=340 \pm 35$ c.p.m.). A dosedependent decrease in proliferation was observed with TGF $\beta 1$ concentrations greater than $0.01 \mathrm{ng} / \mathrm{ml}$. This biphasic effect on DNA synthesis was observed with each epithelial culture tested, but only in the presence of FGF2 (R L Byrne and A T Collins, unpublished results).

Blocking TGF $\beta 1$ action by co-culture with antibody $(10$ and $30 \mu \mathrm{g} / \mathrm{ml})$ in the absence of added FGF2 $\left(10^{-9} \mathrm{M}\right)$ resulted in down-regulation of TGF $\beta 1$ inhibition and therefore increased proliferation (Fig. 2).

\section{Effect of TGF 1 on $m R N A$ levels of CDKIs}

Increasing doses of TGF $\beta 1(0-5 \mathrm{ng} / \mathrm{ml})$ were applied to epithelial cells for a period of 4 days and mRNA transcripts for $\mathrm{p} 15, \mathrm{p} 16, \mathrm{p} 21$ and $\mathrm{p} 27$ were measured by RTPCR (Fig. 3, upper panel). The expression of CDKIs was quantified relative to the expression of the housekeeping gene, GAPDH (Fig. 3, lower panel). The level of p15 mRNA rose with increasing doses of TGF $\beta 1$ for the 4 day exposure. Following an exposure to $5 \mathrm{ng} / \mathrm{ml}$ TGF $\beta 1$ the level of p15 mRNA increased by 
p15

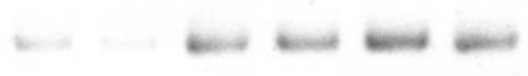

p16

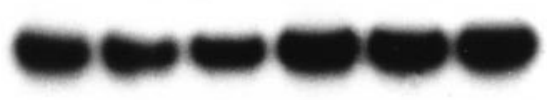

p21
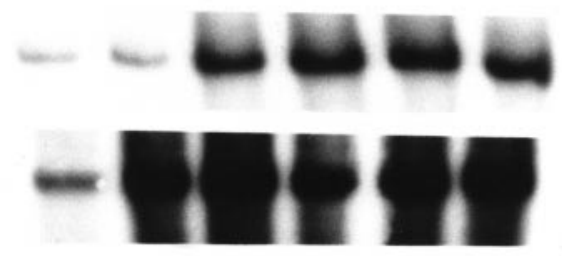

P27

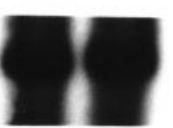

\section{GAPDH}

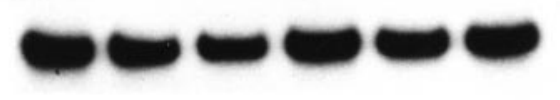

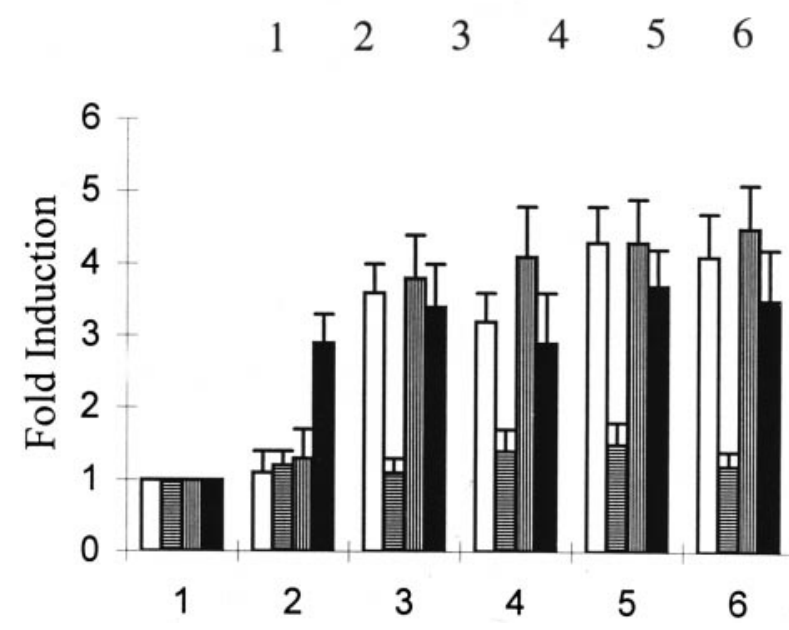

Figure 3 Effect of TGF $\beta 1$ on p15, p16, p21, p27 and GAPDH mRNA expression. Primary prostatic epithelial cells were exposed to basal medium in the absence (lane 1) or presence (lanes 2-6, $0 \cdot 03,0 \cdot 1,0 \cdot 3,1,5 \mathrm{ng} / \mathrm{ml}$ respectively) of TGF $\beta 1$ for 4 days. Upper panel: mRNA was detected by RT-PCR following PAGE. Lower panel: mRNA expression was quantified relative to the expression of $\mathrm{GAPDH}$. The results represent the mean \pm S.D. of at least three independent experiments. Clear box, p15; horizontal bands, p16; vertical bands, p21; black, p27.

approximately 4-fold relative to the level of GAPDH. No detected change was noted for $\mathrm{p} 16 \mathrm{mRNA}$ with a range of TGF $\beta 1$ exposures. Both p21 and p27 mRNA levels increased with higher concentrations of TGF $\beta 1$. For a dose of $5 \mathrm{ng} / \mathrm{ml} \mathrm{TGF} \beta 1$ the levels of $\mathrm{p} 21$ and $\mathrm{p} 27$ rose by 4.5- and 3.5-fold respectively. All reported differences were highly significant $(P<0 \cdot 01)$.

\section{Effects of TGF $\beta 1$ on protein levels of CDKIs}

Epithelial cells were exposed to increasing concentrations of TGF $\beta 1(0-5 \mathrm{ng} / \mathrm{ml})$ for a period of 4 days and the levels

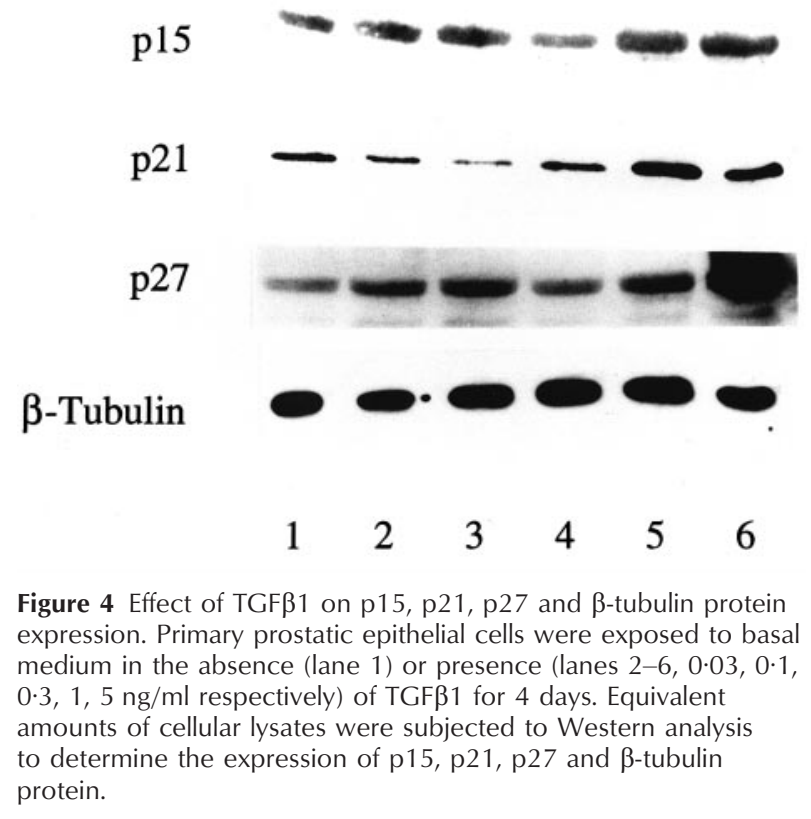

of CDKI proteins were measured by Western analysis performed on cell extracts (Fig. 4). Blots were subsequently re-probed with $\beta$-tubulin to confirm equal loading of cellular protein. The level of p15, p21 and p27 protein increased with the dose of TGF $\beta 1$. The greatest increase relative to control levels was noted with $5 \mathrm{ng} / \mathrm{ml}$ TGF $\beta 1$ for p15, p21 and p27. Densitometric analysis indicated increases in expression of between 4- and 5-fold with $5 \mathrm{ng} / \mathrm{ml}$ TGFß1 for p15, p21 and p27 with independent cultured epithelial cells (data not shown). No detected expression of $\mathrm{p} 16$ protein was observed using two different anti-p16 antibodies, suggesting low level expression of this protein in primary cultured prostatic epithelial cells.

\section{Temporal expression of CDKIs following TGF $\beta 1$ exposures}

A single growth inhibitory dose of $5 \mathrm{ng} / \mathrm{ml}$ TGF $\beta 1$ was given to cells for increasing periods of time $(12,24,48$ and $96 \mathrm{~h}$ ) and the level of mRNA expression of CDKIs was measured by RT-PCR (Fig. 5, upper panel). The change in CDKI mRNA expression was assessed relative to the expression of GAPDH (Fig. 5, lower panel). A rapid induction in the level of $\mathrm{p} 15 \mathrm{mRNA}$ was observed. Following a $12 \mathrm{~h}$ exposure to $5 \mathrm{ng} / \mathrm{ml}$ TGF $\beta 1$ the level of p15 mRNA increased approximately $4 \cdot 5$-fold relative to the control level. The accumulation of p15 mRNA increased with time to $48 \mathrm{~h}(6 \cdot 5$-fold $)$. A similar rapid induction in the level of both p21 and p27 was noted. At $12 \mathrm{~h}$ post-TGF $\beta 1$ exposure the level of p21 and p27 increased 1.2- and 3.4-fold respectively. The levels of these mRNAs showed a further increase in expression up 


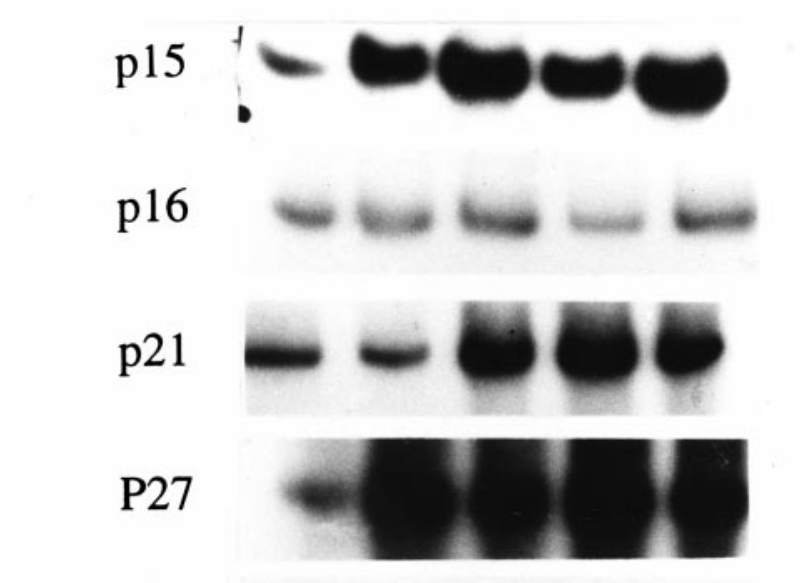

\section{GAPDH}
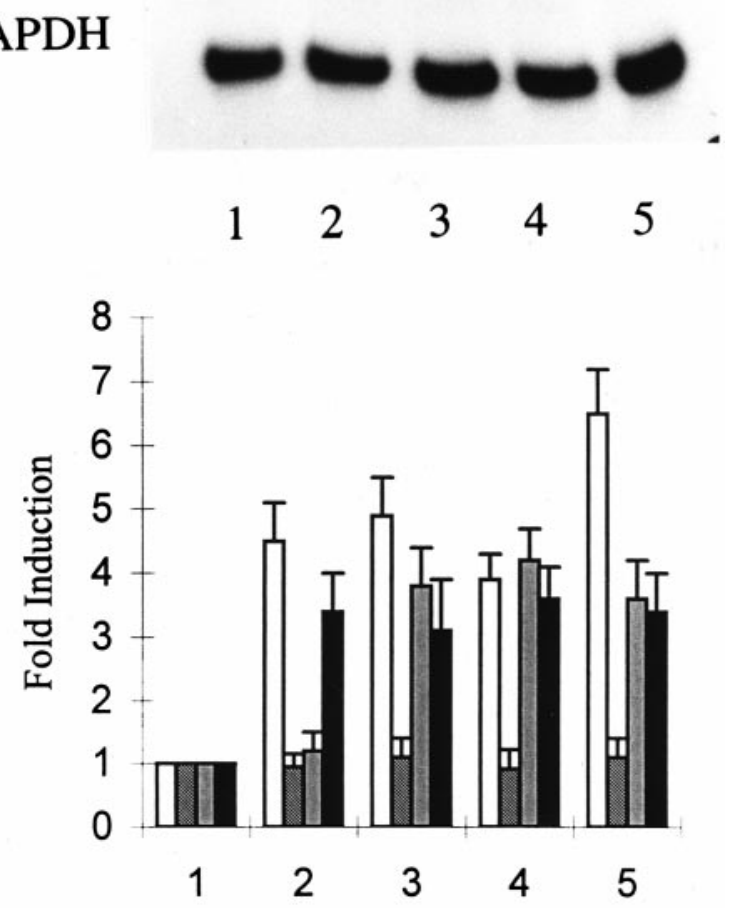

Figure 5 Temporal effect of TGF $\beta 1$ on p15, p16, p21, p27 and GAPDH mRNA expression. Primary prostatic epithelial cells were exposed to basal medium in the absence (lane 1) or presence of $5 \mathrm{ng} / \mathrm{ml} \mathrm{TGF} \beta 1$ for periods of $12,24,48$ and $96 \mathrm{~h}$ (lanes $2-5$ respectively). Upper panel: mRNA was detected by RT-PCR following PAGE. Lower panel: mRNA expression was quantified relative to the expression of GAPDH. The results represent the mean \pm S.D. of at least three independent experiments. Clear box, p15; horizontal bands, p16; vertical bands, p21; black, p27.

to $96 \mathrm{~h}$ exposure to TGF $\beta 1$ (3.6- and 3.4-fold respectively). A single dose of TGF $\beta 1$ given to the cultured epithelial cells produced no change in p16 mRNA level, which was found at very low levels in the cell culture system described here. All reported differences were highly significant $(P<0 \cdot 01)$.

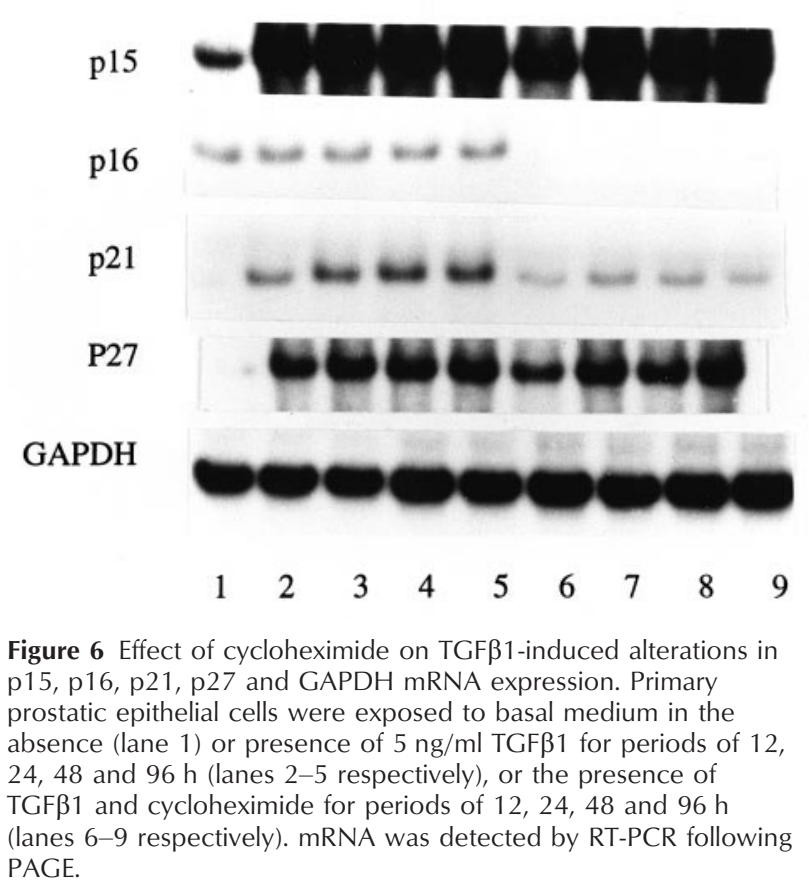

Effects of cycloheximide on TGFß1-induced changes in expression of CDKIs

The effect of addition of the protein synthesis inhibitor cycloheximide, prior to exposure to $5 \mathrm{ng} / \mathrm{ml}$ TGF $\beta 1$ for periods up to $96 \mathrm{~h}$, on the level of CDKI mRNAs was investigated by RT-PCR (Fig. 6). Changes in CDKI mRNAs were measured relative to the level of GAPDH. Cycloheximide failed to prevent the rapid induction of p15 and p21 mRNAs observed following TGF 31 administration for $12 \mathrm{~h}$. The level of $\mathrm{p} 15$ rose approximately 5 -fold after a $24 \mathrm{~h}$ exposure to TGF $\beta 1$, and between 48 and $96 \mathrm{~h}$ the level of p15 remained at about 4-fold above the control level. Cycloheximide exposure also failed to prevent the accumulation of p21 mRNA over the $96 \mathrm{~h}$ period. The p27 mRNA level showed a steady increase in expression in response to TGF $\beta 1$ over the $96 \mathrm{~h}$ period. The level of p 27 mRNA rose to approximately $3 \cdot 5$-fold above the control level at $96 \mathrm{~h}$. In response to combined treatment with TGF $\beta 1$ and cycloheximide the level of p16 mRNA was seen to decrease rapidly by approximately 4-fold at $12 \mathrm{~h}$ and this low level persisted up to $96 \mathrm{~h}$.

\section{Effect of TGFB1 on cell cycle kinetics of epithelial cells}

Epithelial cells were exposed to increasing concentrations of TGF $\beta 1(0-5 \mathrm{ng} / \mathrm{ml})$ for a period of 4 days, removed using PBS/EDTA and analysed for distribution throughout the cell cycle (Fig. 7). These results were confirmed by measurement of cycling cells only (Ki67-positive) using 


\section{- TGFB 1}
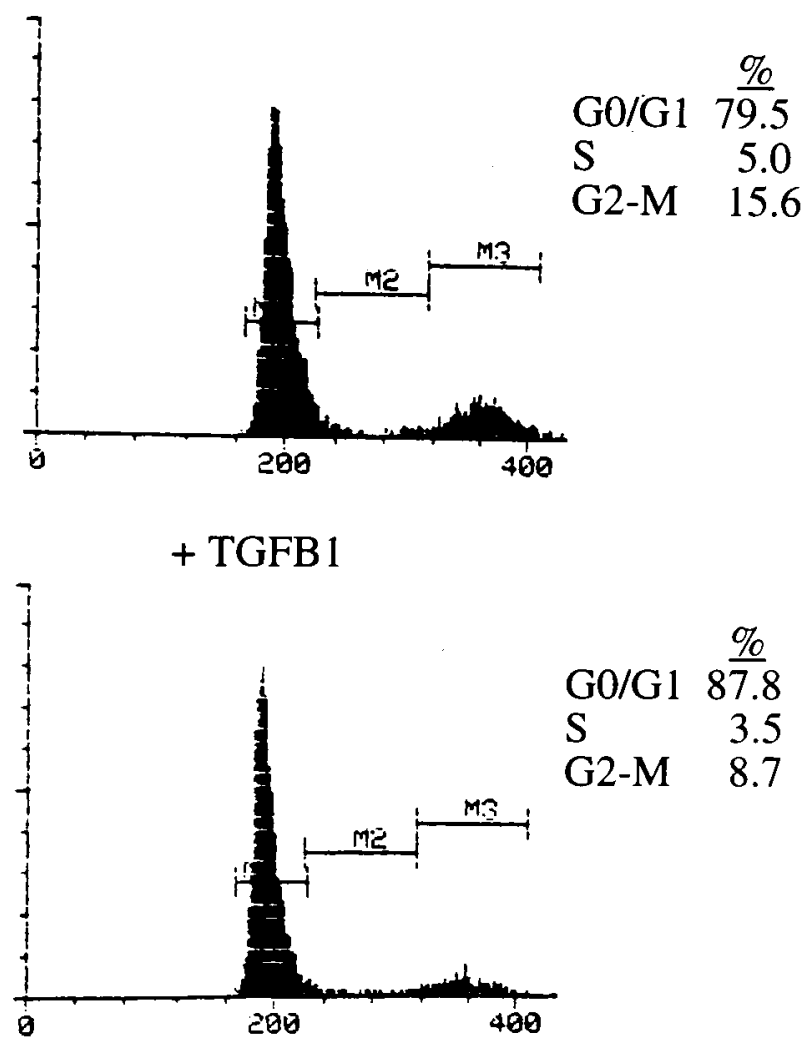

Figure 7 The effects of TGF $\beta 1$ on cell cycle kinetics of primary prostatic epithelial cells. Epithelial cells were exposed to basal medium in the absence or presence of $5 \mathrm{ng} / \mathrm{ml} \mathrm{TGF} \beta 1$ for 4 days. Cells were harvested and stained with propidium iodide and analysed using flow cytometry. The distribution of epithelial cells in the G0-G1 (M1), S (M2) and G2-M (M3) phases of the cell cycle was calculated using LYSIS II software (Becton Dickinson). causes a shift of cells into the G1 phase of the cell cycle suggesting this is where inhibition is most acute. These data show that TGF $\beta 1$ administration is associated with an increased number of cells being placed in G0/G1 (Fig. 7) compared with S or G2/M.

\section{Effect of TGF $\beta 1$ on $R b$ protein expression}

Epithelial cells were exposed to $5 \mathrm{ng} / \mathrm{ml}$ TGF $\beta 1$ for periods up to 4 days and the levels of $\mathrm{Rb}$ protein were measured by Western analysis performed on approximately equal amounts of cell extracts (Fig. 8). Densitometric analysis was performed to determine the change in $\mathrm{Rb}$ following TGF $\beta 1$ exposure. The levels of both hyperphosphorylated $\mathrm{Rb}(\mathrm{ppRb}$ ) and hypo-phosphorylated $\mathrm{Rb}$ protein $(\mathrm{pRb})$ were observed to increase with time for TGF $\beta 1$ exposure. However, the $\mathrm{pRb}$ form was noted to increase relative to the $\mathrm{ppRb}$.

\section{Effect of TGF $\beta 1$ on cdk2-associated kinase activity}

Epithelial cells were cultured in the absence or presence of $5 \mathrm{ng} / \mathrm{ml} \mathrm{TGF} \beta 1$ for 4 days and assayed for cdk2-associated kinase activity following immunoprecipitaion with anticdk2 antibody (Fig. 9). Cells cultured in the absence of TGF $\beta 1$ demonstrated cdk 2 kinase activity as evidenced by the ability to phosphorylate the histone $\mathrm{H} 1$ substrate. However, cells cultured in the presence of TGF $\beta 1$ demonstrated no detected cdk2-associated kinase activity, since they were unable to phosphorylate histone H1.

Cdk2 immunoprecipitated protein extracts were also resolved following SDS PAGE and subjected to Western analysis using anti-cdk2 antibody. Figure 9 shows similar levels of cdk2 protein were immunoprecipitated for cells cultured in the presence or absence of TGF $\beta 1$.

flow cytometry. In the absence of TGF $\beta 1$, there were 84 , 5 and $11 \%$ of cells in G1, S and G2-M phases respectively. Addition of $5 \mathrm{ng} / \mathrm{ml}$ TGF $\beta 1$ changed the distribution of cycling cells so that 92,3 and $5 \%$ of cells were in G1, S and $\mathrm{G} 2-\mathrm{M}$ phases of the cell cycle respectively. Ki67 is expressed in all cells except $\mathrm{G} 0$ and the addition of TGF $\beta 1$

\section{Discussion}

Previous authors have shown that TGF $\beta 1$ has a predominantly inhibitory effect on the proliferation of human prostatic stroma and epithelium. However, some authors

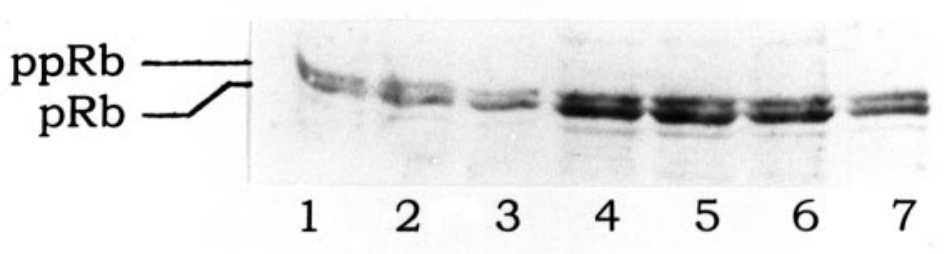

Figure 8 The effect of TGF $\beta 1$ on Rb protein expression. Primary prostatic epithelial cells were exposed to basal medium in the absence (lane 1 ) or presence of $5 \mathrm{ng} / \mathrm{ml}$ TGF $\beta 1$ for periods of 4, 8, 16, 24, 48 and $96 \mathrm{~h}$ (lanes $2-7$ respectively). Equivalent amounts of cellular lysates were subjected to Western analysis to determine the expression of $\mathrm{pRb}$ and $\mathrm{ppRb}$ protein. 
$\mathbf{A}$

\section{$\mathrm{H} 1$}

\section{anti-cdk2}

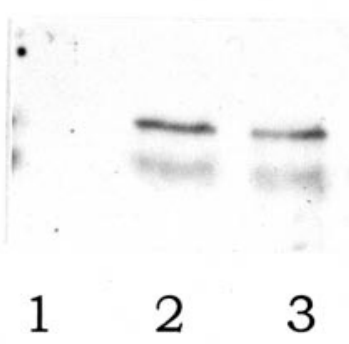

Figure 9 The effect of TGF $\beta 1$ on cdk2 kinase activity. Primary prostatic epithelial cells were exposed to basal medium in the absence or presence (lanes 2 and 3 respectively) of $5 \mathrm{ng} / \mathrm{ml}$ TGF $\beta 1$ for $96 \mathrm{~h}$. A control reaction lacking cell extract was included (lane 1). Cells were immunoprecipitated with anti-cdk2 and assayed for histone $\mathrm{H} 1$ kinase activity (A) and also subjected to Western analysis (B).

have shown a biphasic effect on both cell types with low concentrations being associated with small increases in proliferation, which may be caused by secondary increases in mitogenic growth factors such as basic FGF (Story et al. 1993, Collins et al. 1996). Benign prostatic epithelial cells have been shown by immunohistochemistry to express mitogenic growth factors including FGF2 (Collins et al. 1996) and EGF (Shikata et al. 1984). It is possible that low concentrations of TGF $\beta 1$ in the context of a mixed epithelial/mesenchymal gland such as the prostate may cause the secondary release/synthesis of such growth factors, which may thereby mediate the biphasic effect of TGF $\beta 1$ in prostatic epithelium. Another reason for an apparent increase in proliferation may be the presence of mesenchymal cells which proliferate in response to TGF $\beta 1$ even in apparently pure preparations of human prostatic epithelium in primary culture.

Receptors for TGF $\beta 1$ have been identified in rat ventral prostate where they are negatively regulated by androgens and their up-regulation is involved in the mechanism of castration-induced prostatic cell death (Kyprianou \& Isaacs 1988). Receptors for TGF $\beta 1$ have also been identified in the human prostate cancer cell lines DU145 and PC-3 (Wilding et al. 1989). TGF $\beta 1$ has a mainly inhibitory effect on human prostatic fibroblasts and epithelial cells in culture (Sutkowski et al. 1992, Story et al. 1993). Our studies have confirmed this mainly inhibitory effect, which was most marked in cultures which contained low levels of FGF2. The effect of neutralising antibodies was carried out in the absence of any added mitogens and we observed release of inhibition caused by the presence of TGF $\beta 1$ secreted by the cells.

Immunohistochemical studies (Truong et al. 1993) have identified TGF $\beta 1$ in human prostate and significantly greater staining was found in cancer compared with benign (BPH) specimens. Wilding et al. (1989) found that the androgen-independent cell lines DU145 and PC-3 were inhibited by TGF $\beta 1$, but the androgen-sensitive LNCaP cell line showed no response. In addition, the androgen-independent cell lines were able to secrete TGF $\beta 1$ and contained a high-affinity receptor for TGF $\beta 1$. Thus, in androgen-independent cell lines, there exists an inhibitory autocrine loop for control of cellular proliferation by TGF $\beta 1$. Although increasing levels of TGF $\beta 1$ usually cause an initial inhibition of cell proliferation, further administration can lead to increased growth rates in rat prostate cancer cell lines (Shain et al. 1990). Thus, the effect of TGF $\beta 1$ is dependent on the cell type examined. Other functions of TGF $\beta 1$ that would support growth of tumour cells and may encourage metastasis include its association with extracellular matrix (Ignotz \& Massagué 1986), its ability to inhibit $\mathrm{T}$ and $\mathrm{B}$ lymphocytes leading to defects in host immunity (Kehrl et al. 1986, TorreAmione et al. 1990), and the ability to act as a potent angiogenic factor (Yang \& Moses 1990). Understanding the function of TGF $\beta 1$ in both normal and malignant prostate is further complicated by its interaction with other growth factors which influence cell proliferation. Nevertheless, inhibition is the main effect of TGF $\beta 1$ in prostate stroma and epithelium.

TGF $\beta 1$ binds to serine/threonine kinase receptors (Type I and II), which form heterodimers in the presence of ligand. How this results in the downstream events of TGF $\beta 1$, including induction of some CDKIs, is unclear (Massague et al. 1994). Some members of the TGF $\beta 1$ super-family, including bone morphogenetic proteins (BMPs), result in accumulation of Drosophila MADR1, a homologue of human MAD (Hoodless et al. 1996). Recent studies have shown that binding of TGF $\beta 1$ results in activation of Smad 2 and Smad 3, which associate with Smad 4 to move to the nucleus. Some SMAD proteins are the target of receptor tyrosine kinases such as the EGF receptor. Such SMAD phosphorylation mediated by the Erk family of MAP kinases inhibits the nuclear localisation of Smad 1 initiated by binding of BMPs (Kretzschmar et al. 1997) to TGF $\beta 1$ receptors. This demonstrates the complex interaction between growth factors.

Our study was mainly directed towards the negative regulatory functions of TGF $\beta 1$, which appear to be produced, at least in part, by up-regulation of CDKIs. Whilst p27 was initially identified in TGF $\beta 1$-stimulated cells, p27 mRNA levels are not usually induced and this may imply some post-translational alteration in protein binding with cyclins. Indeed culture of pituitary cells with $10^{-9}$ M TGF $\beta 1$ decreased $\mathrm{p} 27 \mathrm{mRNA}$ and protein levels 
(Qian et al. 1996). Moreover, cells from mice lacking p27 still respond to TGF $\beta 1$ by inhibition (Nakayama et al. 1996). In our experiments the level of p $27 \mathrm{mRNA}$ showed an approximately 3.5 -fold increase in response to a growth inhibitory dose of TGF $\beta 1$ with a corresponding 4-fold increase in the level of p27 protein. Our finding that TGF $\beta 1$ induced the expression of $\mathrm{p} 15$ is in keeping with previous data (Hannon \& Beach 1994) demonstrating a significant up-regulation by 30 -fold. It is not surprising that such massive increases in expression were not found in our experiments on primary human cells from the prostate, because many of these cells are not actively dividing and may be apoptotic. p21 is normally induced by increases in the levels of wild type p53 (Macleod et al. 1995) and in addition to being a CDKI can directly block the replication machinery by binding to proliferating cell nuclear antigen. Our data are in keeping with recent findings that TGF $\beta 1$ can induce p21 levels at both mRNA and protein levels (Akagi et al. 1996). Consistent with other reports, no change in 16 mRNA expression was found in response to TGF $\beta 1$ treatment.

Blocking new protein synthesis with cycloheximide prior to TGF $\beta 1$ exposure appears to show little effect on the TGF $\beta 1$-induced expression of $\mathrm{p} 15, \mathrm{p} 21$ and p27 mRNAs. This implies that the induction of these CDKIs by TGF $\beta 1$ does not require synthesis of new protein but induction probably occurs through the activation of a pre-existing signalling pathway, perhaps involving the Smad proteins. The results observed for p16 mRNA expression showing a rapid, and sustained, decrease in expression suggest that $\mathrm{p} 16 \mathrm{mRNA}$ has a very short half-life and regulation is independent of TGF $\beta 1$, but does require new protein synthesis.

Our findings demonstrate that TGF $\beta 1$ has a mainly inhibitory effect on prostate epithelium and that this inhibition is probably mediated in part by up-regulation of certain CDKIs, particularly p15. The inhibition of cell proliferation is achieved by placing cells in G1 and accompanied by up-regulation of $\mathrm{Rb}$ in its $\mathrm{pRb}$ form, a finding supported by measurable inhibition of cdk2 kinase. The role of TGF $\beta 1$ in prostate cell growth is uncertain, but altered expression and function of stromal cells may be an underlying mechanism of BPH. The increased levels of expression of TGF $\beta 1$ in prostate cancer are not associated with decreased cell proliferation and this finding needs further study to determine whether there is altered control of CDKIs, particularly in hormone unresponsive disease.

\section{References}

Akagi M, Yasui W, Akama W, Yokozaki H, Tahara H, Haruma K, Kajiyama G \& Tahara E 1996 Inhibition of cell growth by transforming growth factor $\beta 1$ is associated with p53 independent induction of p21 in gastric carcinoma cell lines. Japanese Journal of Cancer Research 87 377-384.
Cairns P, Mao L, Merlo A, Lee DJ, Schwabb D, Eby Y, Tokino K, Vanderletf P, Blaugrund JE \& Sidransky D 1994 Rates of p16 (MTS1) mutations in primary tumours with $9 p$ loss. Science 265 415-416.

Chomczynski P \& Sacchi N 1987 Single-step method of RNA isolation by acid guanidinium thiocyanate-phenol-chloroform extraction. Analytical Biochemistry 162 156-159.

Clurman BE \& Roberts JM 1995 Cell cycle and cancer. Journal of the National Cancer Institute 87 1499-1501.

Collins A, Xhiming B, Gilmore K \& Neal DE 1994 Androgen and oestrogen responsiveness of stromal cells derived from the human hyperplastic prostate: oestrogen regulation of the androgen receptor. Journal of Endocrinology 143 269-277.

Collins AT, Robinson EJ \& Neal DE 1996 Benign prostatic stromal cells are regulated by basic fibroblast growth factor and transforming growth factor $\beta 1$. Journal of Endocrinology 151 315-322.

Hannon GJ \& Beach D 1994 p15 (INK4B) is a potential effector of TGF $\beta$-induced cell cycle arrest. Nature 371 257-261.

Hoodless PA, Haerry T, Abdollah S, Stapleton M, O'Connor MB, Attisano L \& Wran JL 1996 MADR1, a MAD related protein that functions in BMP2 signalling pathways. Cell 85 489-500.

Ignotz RA \& Massagué J 1986 Transforming growth factor $\beta$ stimulates the expression of fibronectin and collagen and their incorporation into the extracellular matrix. Journal of Biological Chemistry 261 4337-4345.

Kehrl JH, Wakefield LM, Roberts AB, Jakowlew S, Alvarezmori M, Derynck R, Sporn MB \& Fauci AS 1986 Production of transforming growth factor beta by human $\mathrm{T}$ lymphocytes and its potential role in the regulation of $\mathrm{T}$ cell growth. Journal of Experimental Medicine 163 1037-1050.

Knabbe C, Klein H, Zugmaier G \& Voigt KD 1993 Hormonal regulation of transforming growth factor 2 expression in human prostate cancer. Journal of Steroid Biochemistry and Molecular Biology 47 137-142.

Kretzschmar M, Doody J \& Massagué J 1997 Opposing BMP and EGF signalling pathways converge on the TGF $\beta$ family mediator Smad 1. Nature 389 618-622.

Kyprianou N \& Isaacs J 1988 Identification of a cellular receptor for transforming growth factor beta in rat ventral prostate and its negative regulation by androgens. Endocrinology 123 2124-2131.

Macleod KF, Sherry N, Hannon G, Beach D, Tokino T, Kinzler K, Vogelstein B \& Jacks T 1995 p53 dependent and independent expression of $\mathrm{p} 21$ during cell growth, differentiation and DNA damage. Genes and Development 9 935-944.

Massagué J, Attisano L \& Wrana JL 1994 The TGF $\beta$ family and its composite receptors. Trends in Cell Biology 4 172-178.

Moses HL, Yang EY \& Pietenpol JA 1990 TGF $\beta 1$ stimulation and inhibition of cell proliferation: new mechanistic insights. Mini review. Cell 63 245-247.

Nakayama K, Ishida N, Shirane M, Inomata A, Inoue T, Shishido N, Hori I, Loh DY \& Nakayama K 1996 Mice lacking p27 (kip1) display increased body size, multiple organ hyperplasia, retinal dysplasia and pituitary tumours. Cell 85 707-720.

Polyak K, Kato J, Solomon MJ, Sherr CJ, Massagué J, Roberts JM \& Koff A 1994 p27 (Kip1), a cyclin-cdk inhibitor, links transforming growth factor $\beta$ and contact inhibition to cell cycle arrest. Genes and Development 8 9-22.

Qian X, Jin L, Grande JP \& Lloyd RV 1996 Transforming growth factor $\beta$ and p27 expression in pituitary cells. Endocrinology 137 3051-3060.

Quelle DE, Zindy F, Ashmun RA \& Sherr CJ 1995 Alternative reading frames of the INK4a tumour suppressor gene encode two unrelated proteins capable of inducing cell cycle arrest. Cell 83 993-1000.

Shain S, Lin A, Koger JD \& Karaganis AG 1990 Rat prostate cancer cells contain functional receptors for transforming growth factor $\beta$. Endocrinology 126 818-825.

Sherr CJ 1994 G1 phase progression: cycling on cue. Cell 79 551-555. 
Shikata H, Utsumi N, Hiramatsu M, Minami N, Nemoto N \& Shikata T 1984 Immunohistochemical localization of nerve growth factor and epidermal growth factor in guinea pig prostate. Histochemistry 80 411-413.

Story MT, Hopp KA, Meier DA, Begun FP \& Lawson RK 1993 Influence of transforming growth factor $\beta 1$ and other growth factors on basic fibroblast growth factor level and proliferation of cultured human prostate-derived fibroblasts. Prostate 22 183-197.

Sutkowski DM, Chan-Jye F, Sensibar J, Rademaker A, Sherwood E, Kozlowski J \& Lee C 1992 Interaction of epidermal growth factor and TGF $\beta 1$ in human prostatic epithelial cells in culture. Prostate 21 133-143.

Torre-Amione G, Beauchamp RD, Koeppen H, Park BH, Schreiber H, Moses HL \& Rowley DA 1990 A highly immunogenic tumour transfected with a murine transforming growth factor-beta $1 \mathrm{cDNA}$ escapes immune surveillance. Proceedings of the National Academy of Sciences of the USA 87 1486-1490.
Truong LD, Kadmon D, McCunne BK, Flanders KC, Scardino PT \& Thompson TC 1993 Association of transforming growth factor $\beta 1$ with prostate cancer. Human Pathology 24 4-9.

Weinberg RA 1995 The retinoblastoma protein and cell cycle control. Cell 81 323-330.

Wilding G, Zugmeier G, Knabbe C, Flanders K \& Gelmann E 1989 Differential effects of transforming growth factor beta on human prostate cancer cells in vitro. Molecular and Cellular Endocrinology 62 79-87.

Yang EY \& Moses H 1990 Transforming growth factor $\beta 1$-induced changes in cell migration, proliferation and angiogenesis in the chicken chorioallantoic membrane. Journal of Cellular Biology 111 731-741.

Received 13 February 1998

Revised manuscript received 30 July 1998 Accepted 30 September 1998 